Primljen / Received: 7.6.2011. Ispravljen / Corrected: 30.5.2012.

Prihvaćen / Accepted: 2.6.2012. Dostupno online / Available online: 25.6.2012.

\section{Use of recycled asphalt in the bituminous base course}

Authors:

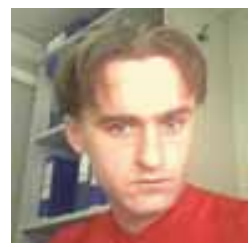

Ivica Androjić

Osijek-Koteks d.d.

ivica.androjic@osijek-koteks.hr

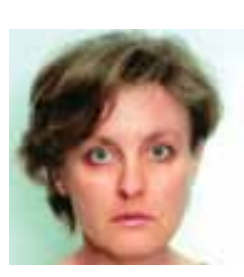

Gordana Kaluder

Kombel d.o.o.

gordana.kaludjer@kombel.hr

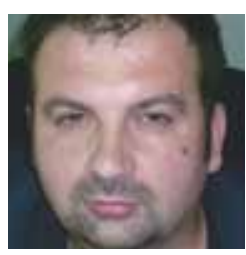

Mario Komljen

Osijek-Koteks d.d.

mario.komljen@osijek-koteks.hr
Ivica Androjić, Gordana Kaluder, Mario Komljen

Professional paper

\section{Use of recycled asphalt in the bituminous base course}

Tests aimed at determining adequacy of use of recycled asphalt in the bituminous base course BNS-32s, for cases of very heavy traffic load, are presented in the paper. The proportion of recycled asphalt used in these asphalt mixes amounted to 20, 25 and 30 percent. Physicomechanical properties of asphalt mixes were tested according the HRN EN-12697. The results obtained show that the use of recycled asphalt in the production of bituminous base course BNS-32s is possible, and that it is an adequate solution from the standpoint of economy and environmental compliance.

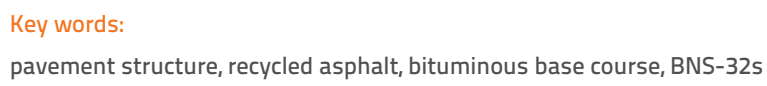

Stručni rad

Ivica Androjić, Gordana Kaluder, Mario Komljen

\section{Primjena recikliranog asfalta u bitumeniziranom nosivom sloju}

U radu su opisana ispitivanja primjene recikliranog asfalta u bitumeniziranom nosivom asfaltnom sloju BNS-32s za vrlo teško prometno opterećenje. Udio recikliranog asfalta $\mathrm{u}$ ispitivanim asfaltnim mješavinama razmatran je u iznosu 20, 25 i 30\%. Ispitivanja fizikalno-mehaničkih svojstava asfaltnih mješavina provedena su prema normi HRN EN-12697. Dobiveni rezultati pokazuju da je primjena recikliranog asfalta u proizvodnji bitumeniziranoga nosivog asfaltnog sloja BNS-32s moguća te predstavlja ekonomski i ekološki opravdano rješenje.

Ključne riječi:

kolnička konstrukcija, reciklirani asfalt, bitumenizirani nosivi asfaltni sloj, BNS-32s

Fachbericht

Ivica Androjič, Gordana Kaluder, Mario Komljen

\section{Anwendung von rezykliertem Asphalt in der bituminösen Tragschichte}

In der Arbeit werden Prüfungen der Anwendung von rezykliertem Asphalt in der bituminösen Asphalttragschichte BNS-32s bei sehr schwerer Verkehrsbelastung aufgezeigt. Der Anteil an rezykliertem Asphalt in den geprüften Asphaltmischungen wurde in dem Betrag von $20 \%, 25 \%$ und $30 \%$ gemessen. Die Prüfung der physikalischen mechanischen Eigenschaften erfolgten nach der Norm HRN EN-12697. Die erhaltenen Resultate zeigen, dass die Anwendung von rezykliertem Asphalt in der Herstellung der bituminösen Asphalttragschichte BNS-32s möglich ist und eine wirtschaftlich und ökologisch gerechtfertigte Lösung darstellt.

Schlüsselwörter:

Fahrbahnkonstruktion, rezyklierter Asphalt, bituminöse Tragschichte, BNS-32s 


\section{Intrudaction}

In the Republic of Croatia, an intensive construction of new motorway sections was initiated in 1990s and so there are currently more than $1500 \mathrm{~km}$ of motorways on the national level. The country has about $30,000 \mathrm{~km}$ of roads and motorways, out of which $7,500 \mathrm{~km}$ are national roads, while county and local roads account for $21,000 \mathrm{~km}[1,2]$. Presently, the need to build new roads and motorways is less and less felt, and a high emphasis is now placed on the maintenance of existing roadways. An increasing traffic load to which roads are exposed on the daily basis, and their inevitable ageing, is causing considerable damage to pavement structures, either in form of cracking or rutting. Until recently, the maintenance of asphalt pavement structures implied construction of new levelling layers made of bituminized material, and an asphaltconcrete wearing course. It was generally believed that the quantities of materials for the construction and maintenance of roads are practically unlimited. However, the operation costs, environmental protection requirements, and the cost of natural stone transport to asphalt plants, have greatly modified former way of thinking so that now new, more efficient and costeffective procedures, aimed at replacing natural materials, are being considered. One of them is the asphalt pavement recycling procedure known as RAP (Reclaimed Asphalt Pavement) that has been in use in many countries for three decades now. It is estimated that more than 500 millions of tons of RAP material are produced worldwide each year [3]. Denmark, Germany and the Netherlands use RAP material for the production of new asphalt courses in more than 50 percent of cases. A similar situation has been registered in Japan and Great Britain, while in our country the use of RAP material is quite negligible [4]. Asphalt pavement recycling enables reuse of material that has already been placed into pavement structure.

Various economic and legal considerations, and recent developments in technology and equipment, have had a positive effect on the implementation of recycling technologies. Limited quantities of natural aggregates, and high price of crude oil, are economic reasons that have spurred development of new recycling technologies and techniques. Current legislation encourages recycling and reuse of materials, reduced generation of waste, and lower $\mathrm{CO}_{2}$ emissions, and sets high penalties and fines for noncompliance. According to its origin, the recycled asphalt can be endogenous - when it originates from the same pavement that is recycled "in situ", or exogenous - when it is transported from an another location to the recycling site. Asphalt pavement recycling methods can be divided into two basic categories:

- method applied in stationary plants, or "in plant" method,

- method applied in situ, or "in place" method.

- In addition, these two recycling methods can be further subdivided, depending on asphalt placing temperature, into two additional categories:

- hot recycling method

- cold recycling method

Advantages and disadvantages of basic recycling categories are presented in Table 1.

\section{Laboratory testing}

Physicomechanical properties of recycled asphalt mix samples, crushed stone material fractions of sedimentary origin, stone flour of category KB-I, and road bitumen 50/70 (according to EN 12591:1999), were tested in the laboratory of the company Osijek-Koteks d.d [7]. The recycled asphalt was obtained by mechanical milling of the existing bituminous wearing course BNHS 16, and the milling produce was then added as a replacement of a part of stone aggregate and paving bitumen for production of the new asphalt mix for the bituminous base course BNS-32s. The proportions of recycled asphalt in asphalt mixes tested amounted to 20, 25 and 30 percent. The following materials were used in the preparation of laboratory asphalt mixes:

- stone flour (Veličanka Quarry),

- stone chippings 0/4, 4/8,8/16, 16/31.5 (Veličanka Quarry),

- paving bitumen 50/70 (Sisak Refinery),

- recycled asphalt (Osijek - West Bypass).

Table 1. Advantages and disadvantages of basic recycling categories, [6]

\begin{tabular}{|c|c|c|}
\hline Recycling method & Advantages & Disadvantages \\
\hline $\begin{array}{l}\text { In place } \\
\text { recycling }\end{array}$ & $\begin{array}{l}\text { - high quality of recycled mix } \\
\text { - grading can be checked } \\
\text { - mix is highly homogeneous } \\
\text { - mix can be improved } \\
\text { - old bitumen is used } \\
\text { - can be reused in a new asphalt wearing course } \\
\text { - high flexibility of use }\end{array}$ & $\begin{array}{l}\text { - potentially more expensive } \\
\text { - high power consumption } \\
\text { - high material transport cost } \\
\text { - RAP material storage } \\
\text { - environmental pollution/emissions }\end{array}$ \\
\hline $\begin{array}{l}\text { In plant } \\
\text { recycling }\end{array}$ & $\begin{array}{l}\text { - full use of RAP material } \\
\text { - highly cost-effective and efficient } \\
\text { - road can rapidly be put to traffic } \\
\text { - favourable for small and big projects } \\
\text { - low cost of transport } \\
\text { - recycling can be made on one traffic lane if needed }\end{array}$ & $\begin{array}{l}\text { - a new surface layer is needed } \\
\text { - problem with heterogeneity of existing asphalt } \\
\text { - long recycling activities are not favourable for } \\
\text { smaller and/or rural roads } \\
\text { - simple recycling equipment is favourable for small } \\
\text { volume and rural roads only }\end{array}$ \\
\hline
\end{tabular}




\subsection{Stone aggregate grading}

Stone chipping fractions $0 / 4,4 / 8,8 / 16,16 / 31.5$, originating from the Veličanka Quarry, with the grading as shown in Table 2, were used in the preparation of trial asphalt mixes. Physicomechanical properties of bituminous asphalt mixes (whose composition is shown in Table 3 ) were also tested. The following physicomechanical properties were tested:

- Density of asphalt sample according to HRN EN 12697-5 [10],

- Density of asphalt mix according to HRN EN 12697-6 [11],

- Voids content according to HRN EN 12697-8 [12],

- Voids in stone mix according to HRN EN 12697-8 [12],
- Percent voids filled with asphalt according to HRN EN 12697-8 [12].

The stone mix grading was determined according to HRN EN 12697-2 [9], and the soluble part of the building bitumen according to HRN EN 12697-1 [8].

\subsection{Preparation of asphalt mixes}

After the recycled asphalt was delivered to the laboratory, the material was dried at the temperature of $25^{\circ} \mathrm{C}$ for 24 hours. The recycled asphalt extraction (separation of bitumen from stone aggregate) was conducted on three samples so as to determine the paving bitumen content and

Table 2. Grading of stone chippings (Veličanka Quarry)

\begin{tabular}{|c|c|c|c|c|c|c|c|c|c|c|}
\hline \multirow{2}{*}{ Sieve $[\mathrm{mm}]$} & \multicolumn{2}{|c|}{ Rock flour } & \multicolumn{2}{|c|}{$0 / 4$} & \multicolumn{2}{|c|}{$4 / 8$} & \multicolumn{2}{|c|}{$8 / 16$} & \multicolumn{2}{|c|}{$16 / 31,5$} \\
\hline & mass \% & $\Sigma$ & mass \% & $\Sigma$ & mass \% & $\Sigma$ & mass \% & $\Sigma$ & $\operatorname{mass} \%$ & $\Sigma$ \\
\hline 0,063 & 72,6 & 72,6 & 6,0 & 6,0 & 1,1 & 1,1 & 0,7 & 0,7 & 0,4 & 0,4 \\
\hline 0,09 & 10,0 & 82,6 & 0,2 & 6,1 & 0,0 & 1,1 & 0,0 & 0,7 & 0,0 & 0,4 \\
\hline 0,125 & 7,70 & 90,3 & 2,5 & 8,6 & 0,0 & 1,1 & 0,0 & 0,7 & 0,0 & 0,4 \\
\hline 0,25 & 7,50 & 97,8 & 9,2 & 15,3 & 0,3 & 1,4 & 0,1 & 0,7 & 0,1 & 0,4 \\
\hline 0,50 & 1,50 & 99,3 & 18,8 & 24,9 & 0,3 & 1,6 & 0,2 & 0,9 & 0,0 & 0,5 \\
\hline 0,71 & 0,70 & 100,0 & 7,1 & 32,0 & 0,2 & 1,9 & $-0,1$ & 0,9 & 0,0 & 0,5 \\
\hline 1,00 & & & 8,9 & 40,9 & 0,4 & 2,3 & 0,1 & 0,9 & 0,0 & 0,5 \\
\hline 2,00 & & & 27,6 & 68,5 & 1,8 & 4,1 & 0,3 & 1,2 & 0,1 & 0,5 \\
\hline 4,00 & & & 28,8 & 97,3 & 13,1 & 17,2 & 0,6 & 1,8 & 0,0 & 0,6 \\
\hline 8,00 & & & 2,6 & 99,9 & 79,2 & 96,4 & 7,5 & 9,3 & 0,1 & 0,7 \\
\hline 11,20 & & & 0,1 & 100,0 & 3,3 & 99,7 & 44,8 & 54,1 & 0,0 & 0,7 \\
\hline 16,00 & & & & & 0,3 & 100,0 & 45,0 & 99,1 & 6,7 & 7,4 \\
\hline 22,40 & & & & & & & 0,9 & 100,0 & 45,7 & 53,1 \\
\hline 31,50 & & & & & & & & & 46,9 & 100,0 \\
\hline \multicolumn{3}{|c|}{$\begin{array}{l}\text { Aggregate fineness modulus } \\
\text { HRN U.E4.014. }\end{array}$} & \multicolumn{2}{|c|}{5,98} & & & & & & \\
\hline \multicolumn{3}{|c|}{$\begin{array}{l}\text { Silty particles } \\
\text { HRN B.B8.036. (mass \%) }\end{array}$} & \multicolumn{2}{|c|}{6,11} & \multicolumn{2}{|c|}{0,01} & \multicolumn{2}{|c|}{0,66} & \multicolumn{2}{|c|}{0,36} \\
\hline \multicolumn{3}{|c|}{$\begin{array}{l}\text { Proportions of undersize particles } \\
\text { HRN U.E4.014. (mass \%) }\end{array}$} & & & \multicolumn{2}{|c|}{17,18} & \multicolumn{2}{|c|}{9,33} & \multicolumn{2}{|c|}{7,41} \\
\hline \multicolumn{3}{|c|}{$\begin{array}{l}\text { Proportions of oversize particles } \\
\text { HRN U.E4.014. (mass \%) }\end{array}$} & \multicolumn{2}{|c|}{2,73} & \multicolumn{2}{|c|}{3,59} & \multicolumn{2}{|c|}{0,94} & & \\
\hline
\end{tabular}

Table 3. Designed asphalt mix composition (proportions of individual constituents)

\begin{tabular}{|c|c|c|c|c|}
\hline Mixes & Material & $\begin{array}{c}\text { Rock flour } \\
{[\%]}\end{array}$ & $\begin{array}{c}\text { Paving bitumen } \\
{[\%]}\end{array}$ & $\begin{array}{c}\text { Recycled asphalt } \\
{[\%]}\end{array}$ \\
\hline Mix I & 2,0 & 2,38 & 30,0 & $\begin{array}{c}\text { Stone chippings } \\
{[\%]}\end{array}$ \\
\hline Mix II & 2,5 & 2,61 & 25,0 & 68,0 \\
\hline Mix III & 3,0 & 2,85 & 20,0 & 72,5 \\
\hline
\end{tabular}

Table 4. Grading of recycled asphalt samples

\begin{tabular}{|c|c|c|c|c|c|c|c|c|c|c|c|c|c|c|c|}
\hline \multicolumn{15}{|c|}{ Stone mix grading according to HRN EN 12697-2 } & \multirow{2}{*}{$\begin{array}{c}\text { BITUMEN } \\
\text { HRN EN 12697-1 }\end{array}$} \\
\hline SIEVE [mm] & 0,063 & 0,09 & 0,125 & 0,25 & 0,5 & 0,71 & 1,0 & 2,0 & 4,0 & 8,0 & 11,2 & 16,0 & 22,4 & 31,5 & \\
\hline AV. VALUE & 11,1 & 12,2 & 13,6 & 17,4 & 23,3 & 27,4 & 32,3 & 47,2 & 66,6 & 89,6 & 97,3 & 100,0 & & & 4,75 \\
\hline Min. content & 9,6 & 10,5 & 11,7 & 14,8 & 19,5 & 22,8 & 26,9 & 39,7 & 58,4 & 85,2 & 96,9 & 100,0 & & & 4,36 \\
\hline Max. content & 12,1 & 13,3 & 14,7 & 18,8 & 25,2 & 29,9 & 35,2 & 51,1 & 71,2 & 92,0 & 97,7 & 100,0 & & & 4,97 \\
\hline Stand. dev. & 1,3 & 1,5 & 1,7 & 2,2 & 3,3 & 4,0 & 4,7 & 6,5 & 7,1 & 3,8 & 0,4 & 0,0 & 0,0 & 0,0 & 0,34 \\
\hline
\end{tabular}


an average grading. The results obtained are shown in Table 4 and Figure 1.

An average grading of recycled asphalt samples is shown in Figure 1. According to its composition, the recycled asphalt mix was defined as the bituminous wearing course with maximum aggregate grain size of $16 \mathrm{~mm}$.

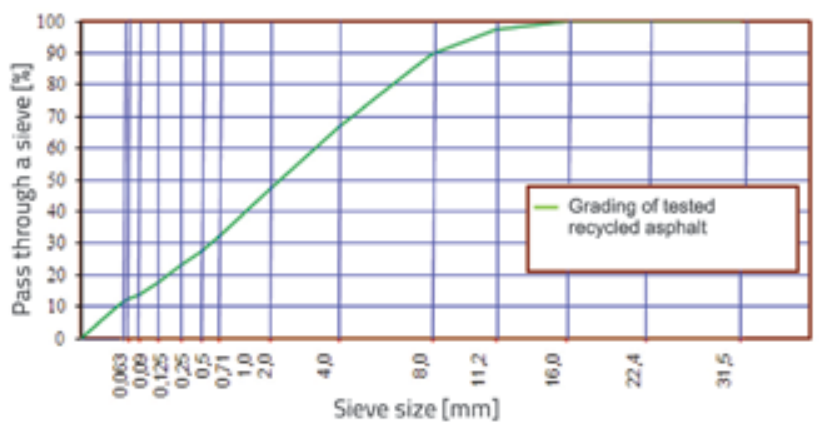

Figure 1. Average grading of asphalt samples

\subsection{Preparation of mix designs and laboratory samples}

The mix design was defined for the bituminous asphalt mix to be used in a bituminous base course. The stone material mix is characterized by the maximum nominal grain size of 31.5 $\mathrm{mm}$, and by narrow grain size distribution boundaries [8]. Laboratory asphalt mixes contain $30 \%, 25 \%$ and/or $20 \%$ of recycled asphalt. Designed and realized asphalt mix samples are presented in Figures $2 a-4 b$. Deviations between the designed and realized asphalt mixes with thirty percent of recycled asphalt are presented in Table 5.

\subsubsection{Asphalt mixes with $30 \%$ recycled asphalt for BNS-32s}

The design grading curve for the asphalt mix with $30 \%$ of recycled asphalt is shown in Figure $2 a$. The grading curve was designed in such a way to make the greatest possible savings in paving bitumen. a) Design grading of asphalt mix

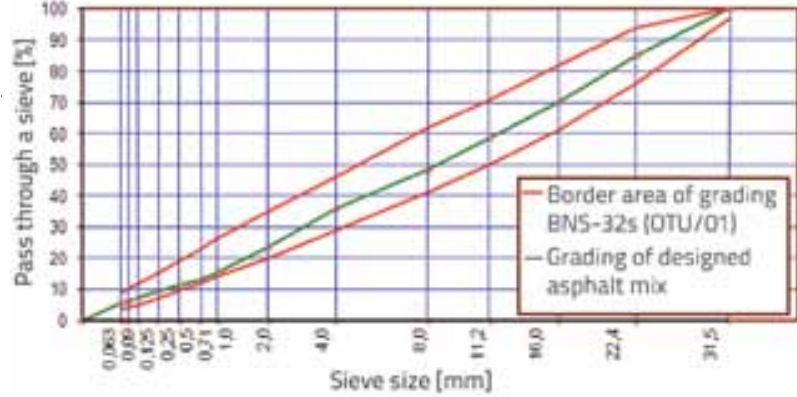

b) Realized grading of asphalt mix

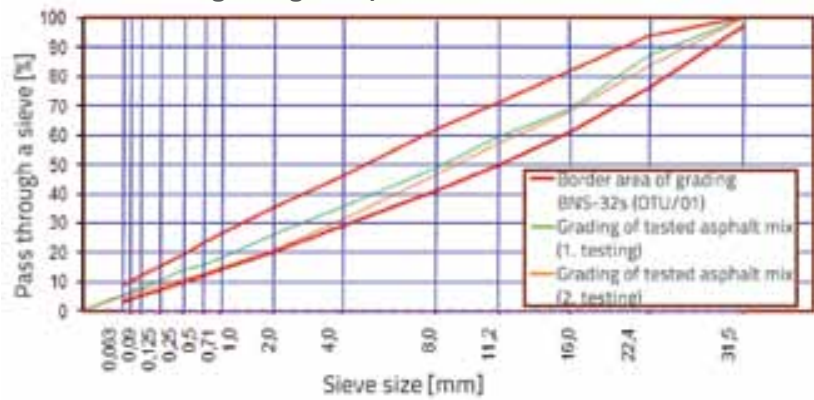

Figure 2. Grading of two asphalt mixes with $30 \%$ of recycled asphalt

\subsubsection{Asphalt mixes with $25 \%$ recycled asphalt for BNS-32s}

The design grading curve for the asphalt mix with $25 \%$ of recycled asphalt is shown in Figure 3a. The grading curve deviation for asphalt mixes with $25 \%$ of recycled asphalt occurs in the range from 0.71 and $8.00 \mathrm{~mm}$, and from 11.20 to $22.40 \mathrm{~mm}$, where the grading curves points to somewhat coarser asphalt mix composition when compared to design values, cf. Figure $3 \mathrm{~b}$.

\subsubsection{Asphalt mixes with $20 \%$ recycled asphalt for BNS-32s}

Realized grading values for asphalt mix with $20 \%$ of recycled asphalt are very close to design values, cf. Figures $4 \mathrm{a}$ and $4 \mathrm{~b}$. It can therefore be concluded that it is easier to achieve design values with smaller recycled asphalt content in the mix.

Table 5. Deviation between the design and realized asphalt mix with $30 \%$ of recycled asphalt

\begin{tabular}{|c|c|c|c|c|c|}
\hline \multirow{2}{*}{$\begin{array}{l}\text { Sieve size } \\
\text { [mm] }\end{array}$} & \multirow{2}{*}{$\begin{array}{c}\text { Design values } \\
{[\%]}\end{array}$} & \multicolumn{2}{|c|}{ First testing } & \multicolumn{2}{|c|}{ Second testing } \\
\hline & & $\begin{array}{c}\text { Test results } \\
{[\%]}\end{array}$ & $\begin{array}{l}\text { Difference compared } \\
\text { to design value }\end{array}$ & $\begin{array}{c}\text { Test results } \\
{[\%]}\end{array}$ & $\begin{array}{l}\text { Difference compared } \\
\text { to design valueg }\end{array}$ \\
\hline 0,063 & 5,39 & 5,50 & 0,11 & 5,00 & $-0,39$ \\
\hline 0,09 & 5,95 & 6,30 & 0,35 & 5,60 & $-0,35$ \\
\hline 0,125 & 6,71 & 7,80 & 1,09 & 6,70 & $-0,01$ \\
\hline 0,25 & 8,59 & 10,40 & 1,81 & 8,60 & 0,01 \\
\hline 0,50 & 11,18 & 13,90 & 2,72 & 11,00 & $-0,18$ \\
\hline 0,71 & 13,05 & 15,80 & 2,75 & 12,40 & $-0,65$ \\
\hline 1,00 & 15,35 & 18,10 & 2,75 & 14,60 & $-0,75$ \\
\hline 2,00 & 23,06 & 25,90 & 2,84 & 20,80 & $-2,26$ \\
\hline 4,00 & 33,91 & 35,20 & 1,29 & 30,80 & $-3,11$ \\
\hline 8,00 & 48,4 & 48,80 & 0,40 & 46,30 & $-2,10$ \\
\hline 11,20 & 58,61 & 59,60 & 0,99 & 57,40 & $-1,21$ \\
\hline 16,00 & 69,29 & 68,90 & $-0,39$ & 67,90 & $-1,39$ \\
\hline 22,40 & 84,51 & 87,10 & 2,59 & 83,30 & $-1,21$ \\
\hline 31,50 & 100,00 & 100,00 & 0,00 & 100,00 & 0,00 \\
\hline bitumen & 3,80 & 3,90 & 0,10 & 3,86 & 0,06 \\
\hline
\end{tabular}


a) Design grading of asphalt mix

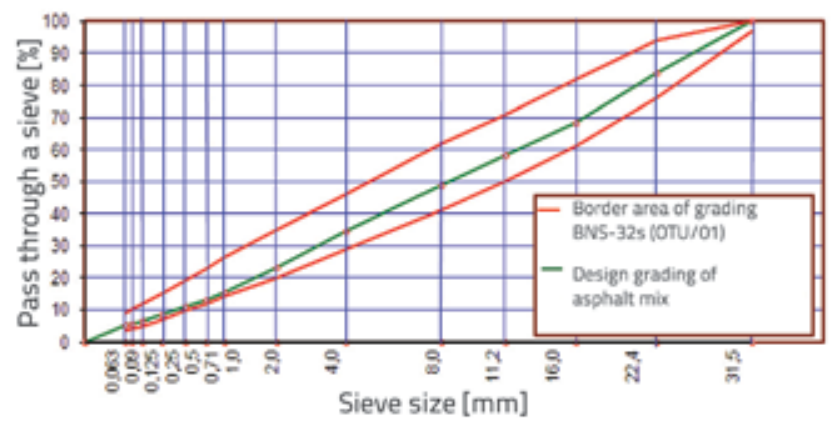

b) Realized grading of asphalt mix

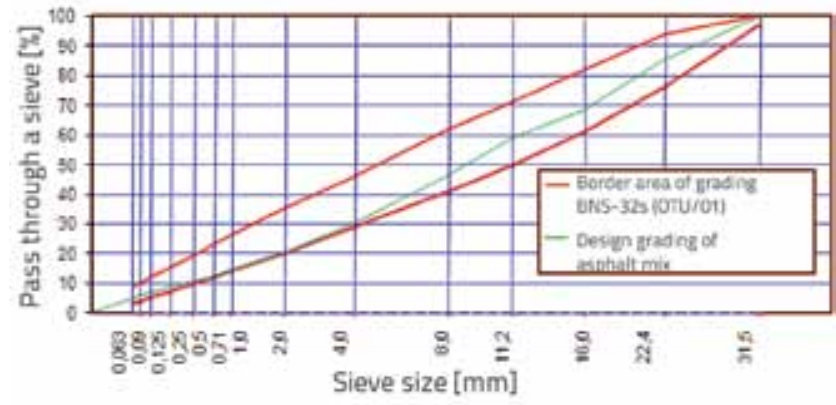

Figure 3. Grading of asphalt mix with $25 \%$ of recycled asphalt

\subsection{Physicomechanical properties of laboratory samples}

Asphalt mixes prepared in laboratory comply with limits specified in OTU (General Technical Requirements), Volume III (Table 5-04-8) for motorways and roads with an extremely high traffic load. Physicomechanical properties of asphalt mixes are given in Table 6.

\subsection{Economic considerations}

After laboratory analysis of recycled asphalt samples obtained by milling the bituminous wearing course BNHS a) Design grading of asphalt mix

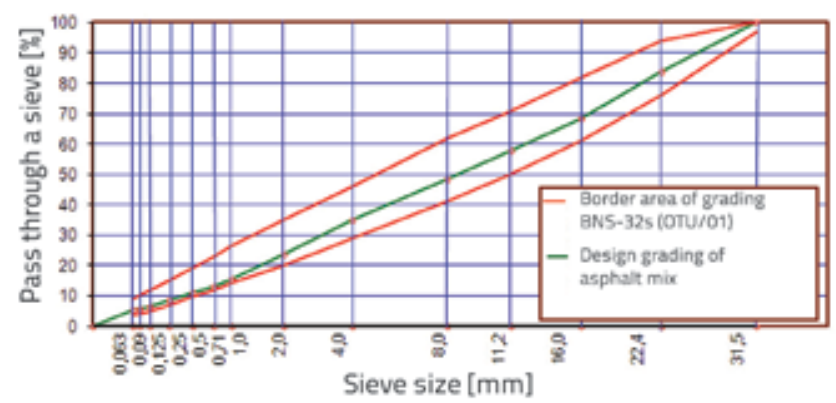

b) Realized grading of asphalt mix

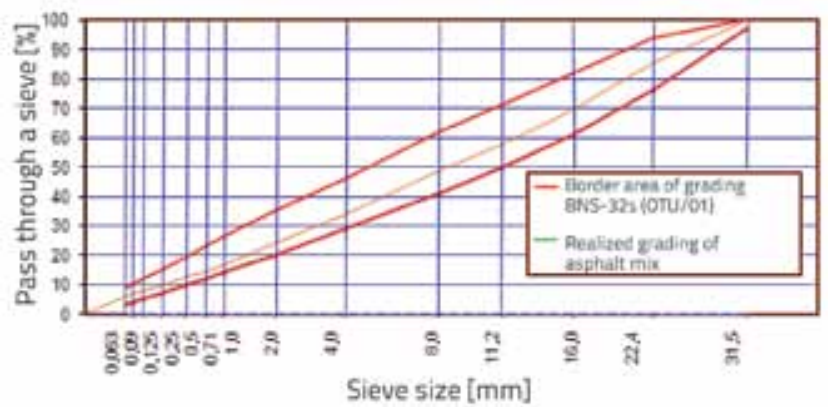

Figure 4. Grading of asphalt mix with $20 \%$ of recycled asphalt

16 it was established that the building bitumen accounts for $4.75 \%$ of the mix. The target building bitumen proportion amounts to $3.8 \%$ for the design asphalt mix for preparation of the bituminous base course BNS-32s. A detailed presentation of savings in asphalt mix sample components, for various proportions of recycled asphalt in the mix, is given in Table 7.

\section{Conclusion}

Results obtained by laboratory testing of samples, with the use of recycled asphalt mix for realization of the bituminous base course BNS-32s, for very high traffic load, and using

Table 6. Physicomechanical properties of asphalt samples for BNS-32s

\begin{tabular}{|c|c|c|c|c|}
\hline $\begin{array}{l}\text { Physicomechanical } \\
\text { properties for BNS }\end{array}$ & $\begin{array}{l}\text { Asphalt mix with } 30 \% \\
\text { of recycled asphalt }\end{array}$ & $\begin{array}{l}\text { Asphalt mix with } 25 \% \\
\text { of recycled asphalt }\end{array}$ & $\begin{array}{l}\text { Asphalt mix with } 20 \% \\
\text { of recycled asphalt }\end{array}$ & $\begin{array}{l}\text { Requiremetn according to } \\
\text { OTU Volume III (Table 5-04-8) }\end{array}$ \\
\hline $\begin{array}{c}\text { Density of asphalt } \\
\text { sample [kg/m³ } \\
\text { (HRN EN 12697-5) }\end{array}$ & $2.509,00$ & $2.509,00$ & $2.495,00$ & - \\
\hline $\begin{array}{c}\text { Density of asphalt mix } \\
{\left[\mathrm{kg} / \mathrm{m}^{3}\right]} \\
\text { (HRN EN 12697-6) }\end{array}$ & $2.675,00$ & $2.685,00$ & $2.661,00$ & - \\
\hline $\begin{array}{l}\text { Voids content [\% (v/v)] } \\
\text { (HRN EN 12697-8) }\end{array}$ & 6,19 & 6,55 & 6,24 & $5-8$ \\
\hline $\begin{array}{c}\text { \% voids in stone mix } \\
\text { [\% (v/v)] } \\
\text { (HRN EN 12697-8) }\end{array}$ & 15,74 & 15,51 & 15,85 & - \\
\hline $\begin{array}{c}\% \text { voids filled with } \\
\text { bitumen [\% (v/v)] } \\
\text { (HRN EN 12697-8) }\end{array}$ & 60,68 & 57,73 & 60,65 & $51-67$ \\
\hline
\end{tabular}


Table 7. Individual proportions of asphalt mix components for BNS-32s

\begin{tabular}{|c|c|c|c|c|c|c|c|}
\hline $\begin{array}{r}\text { Asphalt } \\
\text { mixes }\end{array}$ & $\begin{array}{l}\text { Standard } \\
\text { asphalt mix }\end{array}$ & $130 \%$ of re & led asphalt) & (25\% of rec & led asphalt) & (20\% of rec & led asphalt) \\
\hline $\begin{array}{l}\text { Mix } \\
\text { components }\end{array}$ & $\begin{array}{c}\text { Component } \\
\text { proportion } \\
{[\%]}\end{array}$ & $\begin{array}{c}\text { Component } \\
\text { proportion } \\
{[\%]}\end{array}$ & $\begin{array}{c}\text { Savings with } \\
\text { respect to } \\
\text { standard mix } \\
{[\%]}\end{array}$ & $\begin{array}{c}\text { Component } \\
\text { proportion } \\
{[\%]}\end{array}$ & $\begin{array}{c}\text { Savings with } \\
\text { respect to } \\
\text { standard mix } \\
{[\%]}\end{array}$ & $\begin{array}{c}\text { Component } \\
\text { proportion } \\
{[\%]}\end{array}$ & $\begin{array}{c}\text { Savings with } \\
\text { respect to } \\
\text { standard mix } \\
{[\%]}\end{array}$ \\
\hline Rock flour & 6 & 2,00 & 66,67 & 2,50 & 58,33 & 3,00 & 50,00 \\
\hline Building bitumen & 3,9 & 2,38 & 37,50 & 2,61 & 31,25 & 2,85 & 25,00 \\
\hline Reciklirani asfalt & - & 30,00 & - & 25,00 & - & 20,00 & - \\
\hline $\begin{array}{c}\text { Stone aggregate } \\
0 / 4 \mathrm{~mm}\end{array}$ & 25 & 10,00 & \multirow{4}{*}{$30 \%$} & 13,50 & \multirow{4}{*}{$25 \%$} & 17,00 & \multirow{4}{*}{$20 \%$} \\
\hline $\begin{array}{c}\text { Stone aggregate } \\
4 / 8 \mathrm{~mm}\end{array}$ & 15 & 8,00 & & 9,00 & & 9,00 & \\
\hline $\begin{array}{l}\text { Stone aggregate } \\
8 / 16 \mathrm{~mm}\end{array}$ & 20 & 17,00 & & 16,00 & & 17,00 & \\
\hline $\begin{array}{c}\text { Stone aggregate } \\
16 / 31,5 \mathrm{~mm}\end{array}$ & 34 & 33,00 & & 34,00 & & 34,00 & \\
\hline
\end{tabular}

recycled asphalt proportions of $30 \%, 25 \%$, and $20 \%$, are presented in the paper. The following conclusions were made based on the above-mentioned testing:

- Variability of recycled asphalt mix complicates the process of controlling individual proportions of stone chippings, rock flour, and difference in the paving bitumen requirement.

- After extraction of bitumen from recycled asphalt, it was established that bitumen deviation may attain up to $13.99 \%$.

- Narrow grading limits of the rock mix for BNS-32s complicate considerably the design of the asphalt mixes with higher proportions of recycled asphalt.

- The grading curve deviation for asphalt mixes with $25 \%$ of recycled asphalt occurs in the range from 0.71 and 8.00 $\mathrm{mm}$, and from 11.20 to $22.40 \mathrm{~mm}$, where the grading curves points to somewhat coarser asphalt mix composition when compared to design values.

- Required (design) values for asphalt mixes are easier obtained if the recycled asphalt content is reduced.
- All laboratory asphalt mix samples comply with limits specified in OTU (General Technical Requirements), Volume III (Table 5-04-8) for motorways and roads with an extremely high traffic load.

- Savings in the quantity of paving bitumen, stone chippings, and rock flour greatly depend on the type of recycled asphalt. As the asphalt wearing course with an average bitumen content of $4.75 \%$ was used in this laboratory testing, the savings in bitumen ranged from $25 \%$ to $37.5 \%$ depending on the proportion of recycled asphalt in the design asphalt mix.

Results obtained by testing asphalt mixes containing recycled asphalt for realization of the bituminous base course BNS-32s for very high traffic load conditions, show that this technical solution is fully justified, both from the economic and environmental standpoints. Future studies should focus on the analysis of possibilities for producing these mixes in asphalt plants, and on preparation of test sections so as to test applicability of recycled asphalts in other types of asphalt mixes.

\section{REFERENCES}

[1] Šimun, M., Škerlj, S: Rekonstrukcije asfaltnog kolnika u Hrvatskoj, 10. Slovenski kongres o cestah in prometu, Portorož, 2010.

[2] Drezgić, S: Reforma sustava financiranja javnih cesta Republike Hrvatske, Riznica, RFF, Zagreb, 2008., str. 22-28.

[3] Arand, W: Behavior of asphalt aggregate mixtures at low temperatures, 1990.
[4] Schwabe, Ž: Recikliranje asfaltnih kolničkih konstrukcija, Dani prometnica 2009., Gospodarenje prometnom infrastrukturom, Građevinski fakultet, Zavod za prometnice 2009.

[5] Dridarski, D: Recikliranje postojećih asfaltnih kolovoza.

[6] Schwabe, Ž., Halle, M: Postupak hladnog recikliranja kod obnove cesta, Zbornik 2008. 
[7] Opći tehnički uvjeti za radove na cestama, KNJIGA III., Zagreb, 2001.

[8] HRN EN 12697-1:2003 Bitumenske mješavine - Ispitne metode za asfalt proizveden vrućim postupkom - 1. dio: Topljivi udio veziva.

[9] HRN EN 12697-2:2003 Bitumenske mješavine - Ispitne metode za asfalt proizveden vrućim postupkom - 2. dio: Određivanje granulometrijskog sastava.
[10] HRN EN 12697-5:2003 Bitumenske mješavine - Ispitne metode za asfalt proizveden vrućim postupkom - 5. dio: Određivanje gustoće asfaltnih mješavina.

[11] HRN EN 12697-6:2003 Bitumenske mješavine - Ispitne metode za asfalt proizveden vrućim postupkom - 6. dio: Određivanje gustoće asfaltnih uzoraka.

[12] HRN EN 12697-8:2003 Bitumenske mješavine - Ispitne metode za asfalt proizveden vrućim postupkom - 8. dio: Odredivanje šupljina u asfaltnim mješavinama. 